\title{
Engagement of medical specialty trainees in research: experience at a Lebanese medical school
}

Fouad Fayad, ${ }^{1}$ Ouidade Aitisha Tabesh, ${ }^{1}$ Tamara Lotfi, ${ }^{2}$ Fadi Haddad ${ }^{3}$ and Elie Nemr ${ }^{4}$

${ }^{1}$ Department of Rheumatology, Hotel Dieu de France Hospital and Saint Joseph University of Beirut, Beirut, Lebanon. ${ }^{2}$ Department of Internal Medicine, Faculty of Medicine, American University of Beirut, Beirut, Lebanon; The Global Evidence Synthesis Initiative (GESI) Secretariat, American University of Beirut. ${ }^{3}$ Department of Internal Medicine, Hotel Dieu de France Hospital and Saint Joseph University of Beirut, Beirut, Lebanon. ${ }^{4}$ Department of Urology, Hotel Dieu de France Hospital and Saint Joseph University of Beirut, Beirut, Lebanon. (Correspondence to: Fouad Fayad: fouadfayad@ yahoo.fr).

\begin{abstract}
Background: Many challenges exist to engaging medical students and postgraduate trainees in research in low and middle-income countries.

Aims: This study aimed to assess the motivation of and opportunities for postgraduate medical specialty trainees to engage in medical research, and the perceived obstacles to undertaking research in Lebanon.

Methods: A questionnaire-based survey of all postgraduate clinical trainees was conducted at Saint Joseph University of Beirut medical school, Lebanon. Logistic regression analysis was used to determine factors associated with engaging in research. Odds ratios (OR) and 95\% confidence intervals (CI) are presented.

Results: Of 290 trainees, 252 (87\%) completed the questionnaire; 40.1\% were specializing in medicine, $25.8 \%$ in surgery and $34.1 \%$ in other fields. A total of 122 trainees had participated in research projects: $85.2 \%$ in data collection, $83.6 \%$ in writing of abstracts, $69.7 \%$ in writing papers for publication, $58.2 \%$ in project design and $57.4 \%$ in data analysis. Most trainees had produced considerable research output (82.0\%), with an average of 2.5 publications. Enhancing their curriculum vitae $(\mathrm{OR}=1.90,95 \% \mathrm{CI} 0.84-4.30)$ and enjoying research $(\mathrm{OR}=2.05,95 \% \mathrm{CI} 0.94-4.44)$ were not motivational factors for engaging in research. Trainees were frustrated by the limited research opportunities, citing lack of time as a main factor.

Conclusion: There is a need for additional formal and informal support programmes to encourage postgraduate trainees to engage more in research.

Keywords: biomedical research, medical schools, publications, postgraduate training, Lebanon

Citation: Fayad F; Aitisha Tabesh O; Lotfi T; Haddad F; Nemr E. Engagement of medical specialty trainees in research: experience at a Lebanese medical school. East Mediterr Health J. 2020;26(9):1018-1024. https://doi.org/10.26719/emhj.20.038

Received: 29/05/18; accepted: 08/04/19

Copyright (C) World Health Organization (WHO) 2020. Open Access. Some rights reserved. This work is available under the CC BY-NC-SA 3.o IGO license https://creativecommons.org/licenses/by-nc-sa/3.o/igo
\end{abstract}

\section{Introduction}

An active clinical research culture has clear benefits to health care delivery $(1,2)$. Patients benefit from the development of new therapies and the practice of evidence-based medicine, departments benefit from enhancement of their academic profile and clinicians benefit from career advancement. Involvement of clinicians in medical research as early as possible in their careers, even as medical students, is likely to maximize these benefits (3). Although many countries include research training as a formal part of medical training, this is not universal and there are many challenges to engaging medical student in research (4). Similar arguments apply to postgraduate trainees, who benefit from and contribute to research activity also.

Many barriers to undertaking medical research in developing countries exist, such as lack of funds and facilities, and inadequate training. In addition, little is known about the research needs of trainees in these countries during their specialization, as the opportunities for engaging in research have been less well studied. The aim of this study, therefore, was to assess the motivation of and opportunities for postgraduate specialty trainees to engage in medical research, the perceived obstacles to undertaking research, and the outcomes of their participation in medical research in Lebanon.

\section{Methods}

\section{Participants and setting}

Saint Joseph University of Beirut is one of the largest Lebanese medical schools, with postgraduate training that spans 4 to 6 years. This training consists of four semesters of general training followed by four to six semesters of medical specialization, and two semesters of general training followed by eight semesters of specialty training for surgical specialties. For paediatrics, anaesthetics, histopathology, radiology and other specialties, trainees start specializing immediately in their chosen field. All 290 postgraduate trainees from all specialties at Saint Joseph University of Beirut were invited to participate in the study during September and October 2015. 


\section{Questionnaire}

A modified version of a previously developed questionnaire (4) was used (Appendix 1). The questionnaire was in English and consisted of multiple-choice questions with free text comments where applicable. Two questions addressed barriers to involvement in research with answers on a 5-point Likert scale. The questionnaire was validated by distribution to 25 trainees at Saint Joseph University of Beirut and modified according to their responses.

\section{Statistical analysis}

SPSS, version 22.0 was used for data analysis. To evaluate the relationship between the outcome of interest (involvement in research) and categorical covariates (year and type of specialization, type of hospital, reasons for engaging in research and usefulness of research), we used the chi-squared or Fisher exact tests as appropriate. We used logistic regression analysis to determine the association between the covariates and the outcome. Variables with $P$-value $<0.2$ in the bivariate analysis were included in the logistic regression analysis. Odds ratios (OR) and 95\% confidence intervals (CI) are presented. A Poisson regression approach was used to assess the relationship between number of publications and the following variables: year of specialization, type of specialty and place of work (central teaching hospital, peripheral hospital, or other institutions). An alpha level of 0.05 was considered statistically significant. Free text responses were analysed by the first author. Responses on a Likert scale are reported as: 1-2 = disagree with the statement; 3 = neither agree nor disagree; 4-5 = agree with the statement. Complete-case analysis was performed when dealing with missing data .

\section{Ethical considerations}

The research ethics committee of Saint Joseph University of Beirut approved the study. Participation was optional, and consent was assumed by completion of the questionnaire. Data were anonymized after collection to ensure confidentiality.

\section{Results}

The response rate was $87 \%(252 / 290)$. Most of the postgraduate participants $(101,40.1 \%)$ were trainees in medical specialties, $65(25.8 \%)$ were surgical trainees, the rest $(86,34.1 \%)$ were trainees in nine other specialties (Table 1 ). All postgraduate years were represented (Table 1). Although 250 (99.2\%) of the postgraduate trainees had been involved in research before their graduation in medicine, only $122(48.4 \%)$ were engaged in research during their specialization. The rates of research engagement varied among specialties, with trainees in family medicine having the lowest rate $(2 / 15,13 \%)$; the differences, however, did not reach statistical significance $(P=0.054)$ (Table 1$)$.

Year of specialization was significantly correlated with being involved in research $(P<0.001)$ and the number of publications $(P<0.001)$ (Table 1$)$, with trainees
Table 1 Specialties and academic year the trainees, according to engagement in medical research

\begin{tabular}{|c|c|c|c|}
\hline \multirow[t]{2}{*}{ Variable } & \multicolumn{2}{|c|}{$\begin{array}{l}\text { Engaged in } \\
\text { postgraduate } \\
\text { research } \\
(n=252)\end{array}$} & \multirow{2}{*}{$\begin{array}{l}\text { Publications } \\
\text { per trainee } \\
(n=252) \\
\begin{array}{c}\text { Median } \\
\text { (min-max) }\end{array}\end{array}$} \\
\hline & Yes & No & \\
\hline \multicolumn{4}{|l|}{ Specialty } \\
\hline Medicine $^{\mathrm{a}}$ & 43 & 58 & $0(0-25)$ \\
\hline Surgery $^{a}$ & 37 & 28 & $0(0-13)$ \\
\hline Anaesthesia $^{a}$ & 8 & 11 & $0(0-0)$ \\
\hline Radiology $y^{\mathrm{a}}$ & 8 & 9 & o (o-7) \\
\hline Family medicine $\mathrm{a}^{\mathrm{a}}$ & 2 & 13 & $0(0-0)$ \\
\hline Paediatrics $^{\mathrm{a}}$ & 8 & 6 & $0(0-1)$ \\
\hline Obstetrics/gynaecology & 8 & 2 & $1(0-2)$ \\
\hline Psychiatry & 5 & 1 & $1(0-1)$ \\
\hline Radiotherapy & 1 & 1 & $0(0-0)$ \\
\hline Histopathology & 1 & 1 & $0.5(0-1)$ \\
\hline Paediatric surgery & 1 & 0 & o \\
\hline \multicolumn{4}{|l|}{ Year of training } \\
\hline 1st & 5 & 48 & $0(0-0)$ \\
\hline 2nd & 17 & 36 & $0(0-3)$ \\
\hline 3 rd & 24 & 26 & $0(0-2)$ \\
\hline 4 th & 32 & 18 & $0(0-8)$ \\
\hline 5th & 39 & 2 & $1(0-16)$ \\
\hline 6th & 5 & 0 & $13(1-25)$ \\
\hline
\end{tabular}

There was no correlation between specialty and engagement in research $(P=0.054)$. Year of specialization was significantly correlated with engagement in research $(P<0.001)$ and number of publications $(P<0.001)$

${ }^{a}$ Chi-squared test; Fisher exact test for other comparisons.

${ }^{b}$ Excludes presentations, abstracts and thesis.

in higher postgraduate years having more research experience and publications.

\section{Motivation}

Most trainees stated that research experience was useful $(281,86.5 \%)$ or that it depends $(26,10.3 \%)$, though this was not associated with engagement in research $(P=0.937)$. Some trainees (189) chose only one option as reasons for engaging in research: 140 (55.6\%) said that they would undertake research solely to improve their curriculum vitae (CV), 35 (13.9\%) solely because they would enjoy it, and 14 (5.6\%) solely because it is mandatory.

Univariate analysis showed that enjoying research (n $=73, P=0.190)$ and perceiving research as mandatory to obtain the diploma $(n=42, P=0.523)$ were not associated with engagement in research or not $(P=0.523)$; building a better curriculum vitae, however, was $(n=190, P=$ 0.028). Three variables were used in the multivariable logistic regression analysis (year of specialisation, improving the $C V$, enjoying research), which showed that building a better curriculum vitae $(n=190$; $\mathrm{OR}=1.90,95 \% \mathrm{CI}: 0.84-4.30 ; P=0.123)$ and enjoying research $(n=73 ;$ OR $=2.05,95 \% \mathrm{CI} 0.94-4.44 ; P=0.070)$ were not motivational factors for engaging in research. 
Year of specialisation was still significantly correlated with engagement in research $(n=47 ; \mathrm{OR}=2.80,95 \% \mathrm{CI}$ : 1.26-3.63). Most respondents did not think that lack of personal motivation was an important obstacle to being involved in research: 129 (51.2\%) of the trainees disagreed that it was an obstacle and $69(27.4 \%)$ neither agreed nor disagreed. Many trainees $(164,65.1 \%)$ had approached a potential supervisor for research opportunities.

\section{Opportunities}

Most trainees had research experience (undergraduate or postgraduate) in central teaching hospitals (216/252, 85.7\%); only a very few had research experience in peripheral hospitals $(12 / 252,4.8 \%)$ or in other institutions (24/252, 9.5\%). Postgraduate-only research had similar distribution (central teaching hospital: 101/122, 82.8\%; peripheral hospital: 5/122, 4.1\%; other: 16/122, 13.1\%). Reviewing patient notes and collecting data, and writing abstracts were the most usual forms of participation in research $(83.6 \%$ and $83.6 \%$ of trainees, respectively; Table 2).

Out of the 122 trainees who had participated in post-graduate research, $100(82.0 \%)$ generated output: publications $(64,52.4 \%)$, oral presentations $(41,33.6 \%)$, poster presentations $(34,27.9 \%)$, thesis $(27,22.1 \%)$ or abstracts $(24,19.7 \%)$. Trainees had published on average 2.5 papers (range: $1-25$ ); 45 trainees had only one publication each and three trainees had more than 10 publications each. Only $27(44.3 \%)$ trainees has published as the first author and $34(55.7 \%)$ as co-authors (data missing for three participants). No significant difference was found in the number of publications generated by trainees working in different specialties or places of work.

\section{Perceived obstacles to engaging in research}

Trainees felt frustrated by the lack of opportunities to engage with research: $136(54.0 \%)$ agreed that they felt frustrated while $80(31.7 \%)$ neither agreed nor disagreed. Lack of research within their respective departments was another main concern, with 119 (47.2\%) respondents agreeing that there was a lack of research in their department.

Table 2 Participating roles in postgraduate medical research project

\begin{tabular}{ll} 
Research role & $\begin{array}{c}\text { No. (\%) } \\
(\mathbf{n = 1 2 2})\end{array}$ \\
\hline Reviewing patient notes and collecting data & $104(85.2)$ \\
Writing abstracts & $102(83.6)$ \\
Analysing data & $70(57.4)$ \\
Writing papers for publication & $85(69.7)$ \\
Designing research project protocol & $71(58.2)$ \\
Handing out questionnaires & $52(42.6)$ \\
Conceiving research project idea & $56(45.9)$ \\
Undertaking laboratory work & $19(15.6)$ \\
\hline
\end{tabular}

Many trainees $(110,43.7 \%)$ felt there was a lack of competent advisers, although $80(31.7 \%)$ thought there were competent advisers available. About half of the trainees $(127,50.4 \%)$ thought that supervisors were not interested in involving trainees in research. Lack of time for research was the commonest obstacle reported by the trainees $(176,69.8 \%)$.

Suggestions on how to increase engagement in research included more time for research (35.1\%), more funding $(26.0 \%)$, implementation of a mandatory research course $(23.4 \%)$, more competent and motivated advisers $(18.2 \%)$ and creation of a research department (14.3\%) (Table 3).

\section{Discussion}

Institutions and individuals benefit greatly when clinical staff, including medical students, are involved in active research $(3,5,6)$. We examined perceptions of postgraduate trainees about research opportunities in a medical school in Lebanon. Although trainees were motivated to participate in research, fewer than half had the opportunity to do so because of lack of opportunities, time and support.

A study in Pakistani medical universities found comparable results to ours regarding the value of research and being actively involved in research; only $41.5 \%$ of junior faculty in Pakistan were currently involved in research (7) compared with $48.4 \%$ of our trainees. A report from Saudi Arabia found more respondents recognized the value of research $(97.9 \%)$ than our trainees $(86.5 \%)$ but only $30.4 \%$ were involved in any research activity (8). The Saudi study reported the same barriers as our study (8).

Engagement in research as an undergraduate was associated with greater engagement with academia after graduation (9-11). Medical students in Lebanon have to complete a thesis to graduate, as in other countries such as Peru, Germany and some universities in the United States of America (9), and our trainees had positive attitude towards the value of research. However, this attitude did not translate into high levels of involvement in research in our study. Evidence on the relationship

Table 3 Trainees' suggestions on how to increase postgraduate involvement in medical research

\begin{tabular}{lc} 
Suggestion & No. $^{\text {a }(\%)}$ \\
\hline More time dedicated to research & $27(35.1)$ \\
Providing funds for research & $20(26.0)$ \\
$\begin{array}{l}\text { Implementing a (mandatory) course for research in } \\
\text { medical school }\end{array}$ & $18(23.4)$ \\
More competent and motivated advisers & $14(18.2)$ \\
Creating a research department & $11(14.3)$ \\
Enhancing the value of research & $3(3.9)$ \\
Having statisticians available & $2(2.6)$ \\
Creating computerized database in each department & $1(1.3)$ \\
\hline${ }^{a} 77$ trainees responded to this free text question. Some respondents gave more than one \\
suggestion.
\end{tabular}


between mandatory thesis submission for graduation and future participation in research is lacking and it would be useful to evaluate this relationship further.

The most frequently cited barrier to research in our study was lack of time, which is similar to other studies (4,12-14). Lack of funds and facilities, inadequate training and a lack of recognition of the value of academic activity are also commonly reported barriers to engagement in research in developing countries $(12,15)$. The complex process of securing funding is not limited to developing countries (16) as it is also reported as a major obstacle in developed countries (17). Informal support programmes, such as journal clubs and research interest groups, benefit undergraduates (18) and could be useful in postgraduate training.

Trainees did not think that their own lack of motivation was a barrier to engaging in research, but thought that a lack of interest of potential supervisors was a particular problem. However, only $65.1 \%$ had approached a potential supervisor to get involved in research and 55.6\% said they would undertake research just to improve their curriculum vitae. These attitudes risk demotivating potential supervisors in investing their time and support for such trainees.

Maintaining an active environment conducive to research is important. This environment is possibly lacking in Lebanon as suggested by the trainees' concerns about lack of competent advisors and research carried out in their department. It appears that there is a need for additional formal and informal support programmes to encourage postgraduate trainees to engage more in research.

Funding: None.

Competing interests: None declared.

\section{Participation des étudiants des spécialités médicales à la recherche : expérience dans une école de médecine au Liban}

\section{Résumé}

Contexte : Il existe de nombreux défis à relever pour inciter les étudiants en médecine et les étudiants de cycle supérieur à participer à la recherche dans les pays à revenu faible et intermédiaire

Objectifs : La présente étude avait pour objectif d'évaluer la motivation et les opportunités des étudiants de cycle supérieur dans les spécialités médicales pour s'engager dans la recherche médicale, ainsi que les obstacles perçus dans l'accès à la recherche au Liban.

Méthodes : Une enquête basée sur un questionnaire et incluant tous les étudiants de cycle supérieur en médecine clinique a été menée à l'école de médecine de l'Université Saint-Joseph de Beyrouth (Liban). L'analyse de régression logistique a été utilisée pour déterminer les facteurs associés à un engagement dans la recherche. Les odds ratios (OR) et les intervalles de confiance (IC) à $95 \%$ sont présentés ci-dessous.

Résultats : Sur un total de 292 étudiants, 252 (87\%) ont rempli le questionnaire. Parmi eux, 40,1 \% étaient des étudiants en médecine, $25,8 \%$ en chirurgie et $34,1 \%$ dans d'autres disciplines. Au total, 122 étudiants avaient participé à des projets de recherche : $85,2 \%$ avaient contribué à la collecte de données, $83,6 \%$ à la rédaction de résumés, $69,7 \%$ à la rédaction d'articles de recherche destinés à la publication, $58,2 \%$ à la conception de projet et $57,4 \%$ à l'analyse de données. La majorité des étudiants ( $82 \%$ ) avaient produit un travail de recherche considérable, avec en moyenne 2,5 publications. L'implication dans la recherche de ces étudiants n'était motivée ni par l'amélioration de leur curriculum vitae $(\mathrm{OR}=1,90$; IC à $95 \%: 0,84-4,30)$, ni par un goût pour la recherche (OR = 2,05; IC à $95 \%: 0,94-4,44)$. Les étudiants étaient frustrés par la limitation des opportunités de recherche, principalement due, selon eux, à un manque de temps.

Conclusion : Il est nécessaire de mettre en place des programmes de soutien supplémentaires, formels et informels, pour encourager les étudiants de cycle supérieur à s'engager davantage dans la recherche.

$$
\begin{aligned}
& \text { إشر اك المتدربين في التخصصات الطبية في إجر اء البحوث: تجربة في إحدى كليات الطب في لبنان }
\end{aligned}
$$

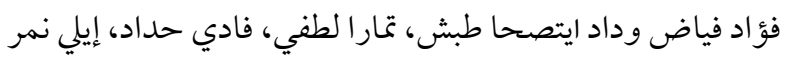

$$
\begin{aligned}
& \text { الخلاصة } \\
& \text { الخلفية: يواجه المتدربون من طلاب كليات الطب والأطباء المُسجلين في الدراسات العليا عدة تحديات بشأن إشراكهم في إجراء البحوث في البلدان } \\
& \text { النامية. }
\end{aligned}
$$

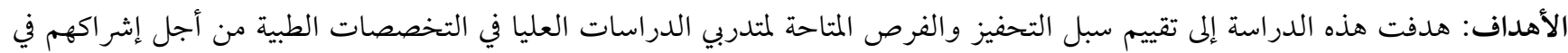

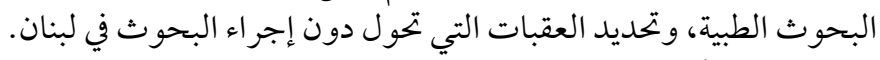

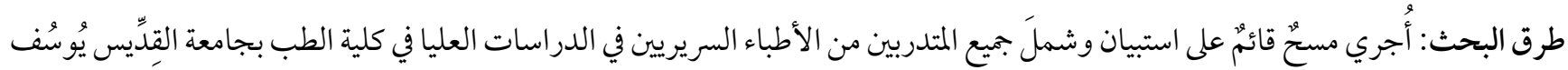


في بيروت، لبنان. واستُخدم تحليل الانحدار اللوجستي لتحديد العوامل المرتبطة بالمشاركة في البحوث. واحتُسبَت نسبة الأرجحية وفواصل الثقة

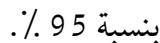

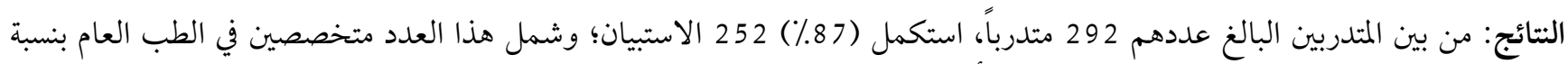

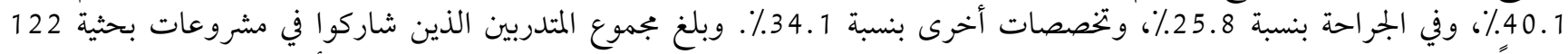

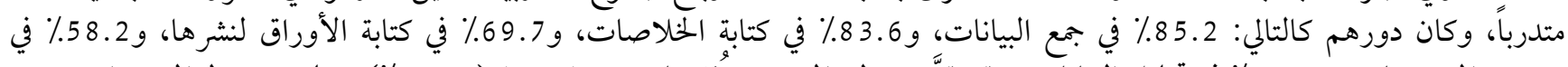

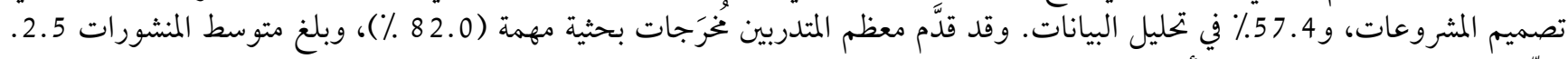
وبيّن تحليل الانحدار اللوجستي أن تحسين السيرة الذاتية للمتدربين (OR (OR= 2.05, \% 9 CI: 0.94-4.44)

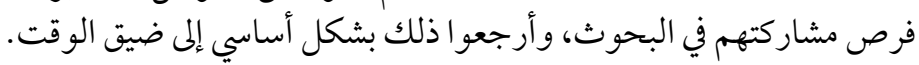

الاستتاجات: هناك حاجة إلى المزيد من برامج الدعم الرسمية وغير الرسمية لتشجيع متدربي الدراسات العليا على المشاركة بصورةٍ أكبر في البحوث.

\section{References}

1. The role of the clinical academic. London: British Medical Association; 2014.

2. NHS England research plan. London: NHS England; 2017 (https://www.england.nhs.uk/wp-content/uploads/2017/04/nhse-research-plan.pdf, accessed 24 May 2019).

3. Gonzalo JD, Dekhtyar M, Hawkins RE, Wolpaw DR. How can medical students add value? Identifying roles, barriers, and strategies to advance the value of undergraduate medical education to patient care and the health system. Acad Med. 2017;92(9):1294301. http//:doi.org/10.1097/ACM.0000000000001662

4. Nikkar-Esfahani A, Jamjoom AA, Fitzgerald JE. Extracurricular participation in research and audit by medical students: opportunities, obstacles, motivation and outcomes. Med Teach. 2012;34(5):e317-24. http//:doi.org/10.3109/0142159X.2012.670324

5. Saint S, Flanders SA. Hospitalists in teaching hospitals: opportunities but not without danger. J Gen Intern Med. 2004;19(4):3923. http//:doi.org/10.1111/j.1525-1497.2004.42002.x

6. Schexnayder S, Starring H, Fury M, Mora A, Leonardi C, Dasa V. The formation of a medical student research committee and its impact on involvement in departmental research. Med Educ Online. 2018;23(1):1424449. http//:doi.org/10.1080/10872981.2018.142 4449

7. Sabzwari S, Kauser S, Khuwaja AK. Experiences, attitudes and barriers towards research amongst junior faculty of Pakistani medical universities. BMC Med Educ. 2009;9:68. http//:doi.org/10.1186/1472-6920-9-68

8. Mitwalli HA, Al Ghamdi KM, Moussa NA. Perceptions, attitudes, and practices towards research among resident physicians in training in Saudi Arabia. East Mediterr Health J. 2014;20(2):99-104.

9. Amgad M, Man Kin Tsui M, Liptrott SJ, Shash E. Medical student research: an integrated mixed-methods systematic review and meta-analysis. PLoS ONE. 2015;10(6):e0127470. http//:doi.org/10.1371/journal.pone.0127470

10. Straus SE, Straus C, Tzanetos K, International Campaign to Revitalise Academic Medicine. Career choice in academic medicine: systematic review. J Gen Intern Med. 2006;21(12):1222-9. http//:doi.org/10.1111/j.1525-1497.2006.00599.X

11. Dorrance KA, Denton GD, Proemba J, La Rochelle J, Nasir J, Argyros G, et al. An internal medicine interest group research program can improve scholarly productivity of medical students and foster mentoring relationships with internists. Teach Learn Med. 2008;20(2):163-7. http//:doi.org/10.1080/10401330801991857

12. Habineza H, Nsanzabaganwa C, Nyirimanzi N, Umuhoza C, Cartledge K, Conard, C, et al. Perceived attitudes of the importance and barriers to research amongst Rwandan interns and pediatric residents - a cross-sectional study. BMC Med Educ. 2019;19(4). https://doi.org/10.1186/s12909-018-1425-6

13. Amin TT, Kaliyadan F, Al Qattan EA, Al Majed MH, Al Khanjaf HS, Mirza M. Knowledge, attitudes and barriers related to participation of medical students in research in three Arab universities. Educ Med J. 2012;4(1):e43-56. http//:doi.org/10.5959/eimj.v4i1.7

14. Clancy AA, Posner G. Attitudes toward research during residency: a survey of Canadian residents in obstetrics and gynecology. J Surg Educ. 2015;72(5):836-43. http//:doi.org/10.1016/j.jsurg.2015.02.007

15. Pallamparthy S, Basavareddy A. Knowledge, attitude, practice, and barriers toward research among medical students: A cross-sectional questionnaire-based survey. Perspect Clin Res. 2019;10(2):73-8. http//:doi.org/10.4103/picr.PICR_1_18

16. Alemayehu C, Mitchell G, Nikles J. Barriers for conducting clinical trials in developing countries- a systematic review. Int J Equity Health. 2018;17(1):37. http//:doi.org/10.1186/s12939-018-0748-6

17. Moses H, Matheson DHM, Cairns-Smith S, George BP, Palisch C, Dorsey ER. The anatomy of medical research: US and international comparisons. JAMA. 2015;313(2):174-89. http//:doi.org/10.1001/jama.2014.15939

18. Chang Y, Ramnanan CJ. A review of literature on medical students and scholarly research: experiences, attitudes, and outcomes. Acad Med. 2015;90(8):1162-73. http//:doi.org/10.1097/ACM.0000000000000702. 


\section{Appendix 1}

\section{Questionnaire}

Involvement of specialty trainees in medical research: The experience at a Lebanese medical school

(1) What is your medical specialty?

\begin{tabular}{|c|c|c|c|}
\hline$\square$ Medicine & $\square$ Surgery & $\square$ Pediatrics & $\square$ Family Medicine \\
\hline$\square$ Psychiatry & $\square$ Anesthesia & $\square$ Radiology & \\
\hline
\end{tabular}

(2) What is your year of specialization?
$\square R 1$
$\square \mathrm{R} 2$
$\square$ R3
$\square$ R4
$\square \mathrm{R}_{5}$
$\square R 6$

(3) Do you think research experience is useful for specialty trainees?
$\square$ Yes
$\square$ No
$\square$ It depends to the future medical career

\section{(4) Why do you want to carry out research work?}

$\square$ You enjoy research

$\square$ You want your CV to look better

$\square$ It is mandatory to obtain the diploma

$\square$ Other. .

(5) Have you approached anyone about getting involved in research work?

$\square$ Yes $\quad \square$ No

(6) Have you ever been involved in research?

$\begin{array}{lll}\text { - Before medical graduation? } & \square \text { Yes } & \square \text { No } \\ \text { If yes, please select and specify the number in brackets: } & \\ \text { Published Paper ( ) } & \text { Published abstract ( ) } & \text { Oral Presentation ( ) } \\ \text { Poster Presentation ( ) } \quad \text { Thesis ( ) } & \end{array}$

- During specialty? $\quad \square$ Yes $\quad \square$ No

If yes, please select and specify the number in brackets:

Published Paper ( ) Published abstract ( ) Oral Presentation ( )

Poster Presentation ( ) None ()

(7) If your research work was presented/published, where were you on the list of authors?

$\square$ First author $\quad \square$ Co-author $\quad \square$ None

(8) Where did you carry out the research work?

$\square$ Central Teaching Hospital $\quad \square$ Peripheral Hospital

$\square$ Other.

(9) What specialty or specialties have you undertaken your research work?

\begin{tabular}{|c|c|c|c|}
\hline$\square$ Medicine & $\square$ Surgery & $\square$ Pediatrics & $\square$ Family Medicine \\
\hline$\square$ Psychiatry & $\square$ Anesthesia & $\square$ Radiology & \\
\hline
\end{tabular}


(10) What level in training was the individual who got you involved in research work?

$\square \mathrm{MD} \quad \square \mathrm{MD}, \mathrm{MSc} \quad \square \mathrm{MD}, \mathrm{PhD} \quad \square \mathrm{PhD}$

(11) What part did you play in the research work? (You can choose more than one)

$\square$ Conception of the idea

$\square$ Design of the research project

$\square$ Going through patient notes and collecting data

$\square$ Handing out questionnaires

$\square$ Lab work

$\square$ Analyzing data

$\square$ Writing of abstracts

Designing posters for presentation

(Local / National / International) please circle type of meeting

Delivering oral presentation

(Local / National / International) please circle type of meeting

$\square$ Writing of papers for publication

(12) Have you been frustrated by lack of opportunities available to carry out research work?

(' 1 ' = completely disagree, ' 5 ' = completely agree)

$\begin{array}{lllll}1 & 2 & 3 & 4 & 5\end{array}$

(13) What do you think are the main obstacles in getting involved in research work? (Indicate to what extent you agree with the following statements: ' 1 ' = completely disagree, ' 5 ' = completely agree)

Lack of motivation on your behalf

$\begin{array}{lllll}1 & 2 & 3 & 4 & 5\end{array}$

Lack of competent advisors

$\begin{array}{lllll}1 & 2 & 3 & 4 & 5\end{array}$

Lack of research carried out in your department

$\begin{array}{lllll}1 & 2 & 3 & 4 & 5\end{array}$

Lack of interest by the supervisors to get specialty trainees involved in research work

$\begin{array}{lllll}1 & 2 & 3 & 4 & 5\end{array}$

Lack of time due to other commitments

$\begin{array}{lllll}1 & 2 & 3 & 4 & 5\end{array}$

Other

(14) Do you have any recommendations for increasing specialty trainees' opportunities for involvement in research?

(15) Any other comments: 